\title{
Physicochemical Characteristics of Pigeonpea and Mung Bean Starches and Their Noodle Quality
}

\author{
U. SINGH, W. VORAPUTHAPORN, P.V. RAO, and R. JAMBUNATHAN
}

\begin{abstract}
This study compared the properties of pigeonpea and mung bean starches and noodles made from each. No large differences in size and shape of respective starch granules were observed. The degree of syneresis of pigeonpea starch was nearly three times that of mung bean starch. Swelling power of pigeonpea starch was considerably lower at $60^{\circ} \mathrm{C}$ and $70^{\circ} \mathrm{C}$ but it did not differ markedly at $80^{\circ}$ and $90^{\circ} \mathrm{C}$. The Brabender viscosity patterns of $6 \%$ starch pastes of pigeonpea and mung hean indicated no pasting peak during heating to $95^{\circ} \mathrm{C}$; neither showed breakdown of the hot paste. Sensory tests indicated that pigeonpea starch of dhal (decorticated dry split cotyledons) was as good for noodle preparation as mung bean dhal starch.
\end{abstract}

\section{INTRODUCTION}

PIGEONPEA (Cajanus cajan L.) is a nutritionally important grain legume of the tropical and subtropical regions of the world. Attention has been paid to improve the nutritional quality of grain legumes as they are important for the nutrition of humans and monogastric animals (Bressani, 1973). Protein and starch are the principal constituents of grain legumes. Although legume seed proteins have been the subject of numerous studies in the past, only limited information is available on various legume starches (Leach et al., 1959; Schoch and Maywald, 1968; Lai and Varriano-Marston, 1979; Yang et al., 1980; Tjahjadi and Breene, 1984). Generally, legume starch pastes are more viscous than those of cereal starches, indicating that legume starches have a higher resistance to swelling and rupture than do cereal starches (Lineback and Ke, 1975).

Legume starches have occupied an important place in noodle preparation in several countries of the world, and mung bean (Vigna radiata) has been reported as the best raw material for starch noodle preparation (Chen, 1978). Lii et al. (1979) investigated the potential of other legume starches for noodle preparation. Yang et al. (1980) examined the properties of kidney bean (Phaseolus vulgaris) starches with special reference to noodle preparation. Lii and Chang (1981) prepared noodles from adzuki bean (Vigna angularis) starch and reported that noodles were of acceptable quality but not as good as mung been starch noodles.

Although India accounts for about $85 \%$ of the world's supply of pigeonpea, this legume is becoming popular in several countries of Africa and South East Asia (ICRISAT, 1981). In these countries, the utilization of pigeonpea, including its alternative uses for humans and animals, is receiving increasing attention from food scientists and nutritionists.

The International Crops Research Institute for the Semi-Arid Tropics (ICRISAT) has a global mandate to improve the productivity and enhance utilization of pigeonpea. In India, pigeonpea is mostly consumed after dehulling in the form of dhal (decorticated split cotyledons) after cooking it in water to a desirable softness, whereas in some African countries whole sceds of pigconpea arc consumed after boiling. Efforts arc

Authors Singh, Rao, and Jambunathan are affiliated with the International Crops Research Institute for the Semi-Arid Tropics (ICR/SAT), Patancheru, Andhra Pradesh 502 324, India.

Author Voraputhaporn is affiliated with Faculty of Food Technology, Khon Kaen Univ. Khon Kaen, Thailand. needed to explore some new food uses for pigeonpea, such as starch-based food products, noodles and fermented food products (e.g., tempeh), to enhance its utilization in some South East Asian countries. With this objective in view, the physicochemical properties of pigeonpea starch and its noodle quality were studied, and the results compared with those obtained with mung bean starch to examine the suitability of pigeonpea starch for making acceptable noodles.

\section{MATERIALS \& METHODS}

ONE CULTIVAR (C 11) of pigeonpea and one cultivar (PS 16) of mung bean were grown at ICRISAT Center, Patancheru, India during the rainy season 1987 . The harvested seeds were cleaned, soaked for $4 \mathrm{hr}$ at room temperature $\left(25=1^{\circ} \mathrm{C}\right)$ and dried in the oven at $55^{\circ} \mathrm{C}$. They were decorticated, using the Tangential Abrasive Dehulling Device (TADD) to prepare dhal (Singh et al., 1989).

\section{Chemical analysis}

For chemical analysis, about $200 \mathrm{~g}$ each of whole seed and dhal samples of pigeonpea and mung bean were ground in a Udy cyclone mill, using the $0.4 \mathrm{~mm}$ screen. Whole seed and dhal (dccorticated dry split cotyledons) samples of pigeonpea and mung bean werc analyzed as described previously for protein (Singh and Jambunathan, 1981), fat, ash, crude fiber (AOAC 1975) and soluble sugars and starch (Singh et al., 1980). Isolated starch samples were also analyzed for starch, protein, ash and crude fiber according to methods cited above. Amylose in the isolated starch sample was determined, using the method of Williams et al. (1958).

\section{Isolation of starch}

Starch was isolated from the whole seed and dhal samples, using the method of Schoch and Maywald (1968) with some minor modifications as follows: legume samples were steeped in water overnight, washed and ground in a Waring Blendor at low speed for $2 \mathrm{~min}$. The slurry was filtered through a cloth bag (about 80 mesh) and then through a standard sieve (200 mesh). The filtrate was set aside for about $4-6$ hr to sediment the starch. For increased starch yield, the starch was reslurried in water and sedimented $2-3$ times or until the water was clear. The recovered starch was then dried in a hot air oven at $50^{\circ} \mathrm{C}$. The starch yield was expressed as the percentage recovery of the determined quantitiy of starch in the sample.

\section{Microscopic analysis of starch}

Size and shape of isolated starch granules were examined, using a light microscope. Starch granules were stained with $0.1 \%$ iodine solution. For this, $100 \mathrm{mg}$ iodine was mixed in $100 \mathrm{~mL}$ of $0.1 \%$ potassium jodide solution. Starch granule sizes were determined with an eyepiece micrometer.

Gelatinization temperature of starch was determined, using a light microscope, congo-red $(0.2 \%)$ was used as a stain. The aqueous solution of starch was heated, using a mini block heater, and samples were taken from $60^{\circ} \mathrm{C}$ onwards at $1^{\circ} \mathrm{C}$ intervals until the gelatinization temperature was reached. Starch granules were stained at initial, midpoint ( $50 \%$ stained) and final ( $90 \%$ stained). The temperature at which $90 \%$ of the starch granules were stained was recorded. 
Table 1-Chemical composition of whole seed and dhal of pigeonpea (cultivar C 11) and mung bean (cultivar PS 16):

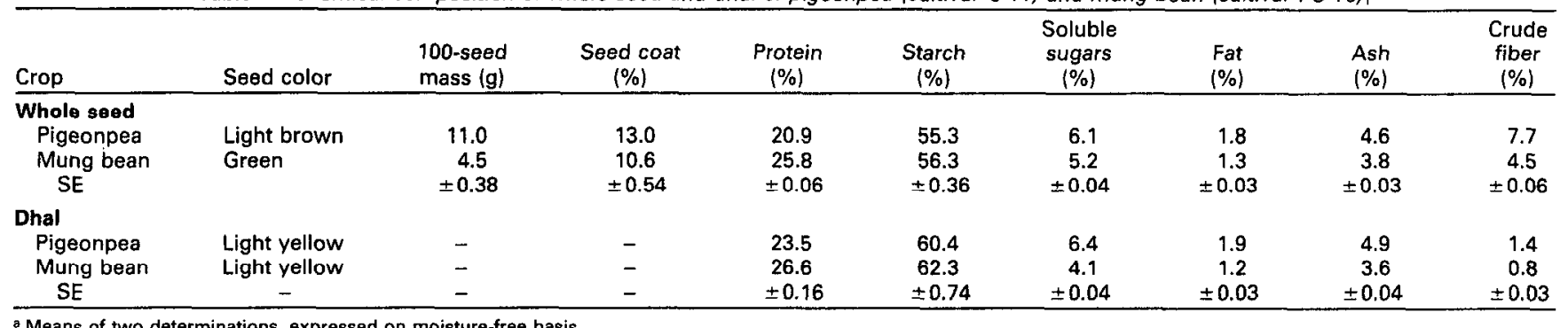

Means of two determinations, expressed on moisture-free basis.

\section{Swelling power and solubility determination}

Isolated starch (200 $\mathrm{mg}$ ) was used for swelling power and solubility determinations from $60-90^{\circ} \mathrm{C}$ at $10^{\circ} \mathrm{C}$ intervals, as per the method of Leach et al. (1959).

\section{Gel strength and viscosity measurements}

Gel strength was measured using a compression cell $(0-5 \mathrm{~kg}$ full scale) in an Instron food testing machine (Model 1140, High Wycombe, Derkskire, UK). Thirty-five $\mathrm{mL}$ of $6 \%$ starch solution, previously heated at $95^{\circ} \mathrm{C}$ for $10 \mathrm{~min}$, was poured into a round moisture dish ( $5 \mathrm{~cm}$ diameter) and stored at room temperature for $12 \mathrm{hr}$. Uniformly polymerized round starch gel slabs of $1 \mathrm{~cm}$ thickness were removed from the moisture dishes and compression forces were measured by pressing gel slabs between two flat plates which were considerably larger than the sample so that no puncture took place. Samples were compressed to $0.5 \mathrm{~cm}$ at a crosshead speed of $20 \mathrm{~cm} \mathrm{~min}^{-1}$.

The degree of syneresis of starch gels was determined from the volume of watcr (mL) scparated from the gel after storagc at $4^{\circ} \mathrm{C}$ for $12 \mathrm{hr}$ as per Yang et al. (1980). The gel consistencies of the $6 \%$ starch gels of pigeonpea and mung bean were measured as per Radley (1976). The isolated starch (120 $\mathrm{mg}$ ) was heated in $2 \mathrm{~mL}$ distilled water in $15 \times 150 \mathrm{~mm}$ test tubes for $5 \mathrm{~min}$ at $95^{\circ} \mathrm{C}$. After standing for $30 \mathrm{~min}$ at room temperature $\left(25 \pm 1^{\circ} \mathrm{C}\right)$, test tubes were placed horizontally on a graph sheet and gel spread (length) measured.

Viscosity values were obtained with a Brabender viscoamylograph (Model Viscograph E), using 6\% starch concentration, as per Lii and Chang (1981).

\section{Noodle prparation}

Soft and hard noodles of mung bean and pigeonpea starches were prepared, as per Chen (1978), with the following minor modifications: For preparing soft noodles, dry starch and water $(1: 7 \mathrm{w} / \mathrm{v})$ were boiled for $5 \mathrm{~min}$, and the starch gel thus obtained was extruded into cold water, using a locally designed extruder with a hole opening of about $2 \mathrm{~mm}$ diameter. Soft transparent noodles $15-20 \mathrm{~cm}$ long, with moisture content of $60-65 \%$, were obtained. For preparing hard noodles, dried starch and cooked starch $(95: 5 \mathrm{w} / \mathrm{w})$ were mixed in water in the ratio of $1: 7(w / v)$ and extruded into boiling water. Noodles were separated, kept at $5^{\circ} \mathrm{C}$ in the refrigerator overnight and sun-dried. Freshly cooked noodles were evaluated by 10 trained panel members for color, texture, clarity, uniform appearance and general acceptability, using a score of 4 for excellent and 1 for poor quality. These sensory properties were explained to the panel members before the sensory cvaluation.

\section{Statistical analysis}

Two replicates were used for the determination of each constituent. Standard error was determined by "one way analysis of variance" (Snedecor and Cochran, 1967). Standard error (SE) indicated in the Tables is the pooled error of replications.

\section{RESULTS \& DISCUSSION}

THE CONCENTRATIONS of various chemical constituents in the whole seed and dhal samples of pigeonpea and mung bean are shown in Table 1 . Soluble sugars, fat and ash, contents of pigeonpea whole seed and dhal were noticeably higher than those of the mung bean (Table 1). Protein content of pigeonpea was considerably lower than that of mung bean, whereas no large differences in starch content were observed. Crude fiber contents of both whole seed and dhal were remarkably higher in pigeonpea than in mung bean, this might have interfered in starch extraction as discussed below.

The starch yields from both whole seed and dhal samples of mung bean were higher than those of the pigeonpea (Table 2 ). Differences in whole seed samples were more pronounced, which might have been due to differences in their fiber contents. However, the starch yields from mung bean and pigeonpea were considerably higher than those from other legumes (Lai and Variano-Martson, 1979; Schoch and Maywald, 1968). But the results of the present study indicated that starch was more extractable from mung bean than from pigeonpea.

Chemical analysis of the isolated starches showed that the starch fraction contained $0.10-0.18 \%$ protein, $0.03-0.09 \%$ ash and $0.0-0.11 \%$ crude fiber, indicating high purity of the starch fractions (Table 2). No large difference in the amylose content of pigeonpea and mung bean starches were observed. However, amylose contents of these legumes are considerably higher than those of black bean (35.1\%) (Lai and Varriano-Marston, 1979) and mung bean (34.9) (Biliaderis et al., 1971).

Microscopic examination (600X) showed that most pigeonpea and mung been starch granules had irregular shapes, which varied from oval to round to bean-shaped (Fig. 1). A large variability existed in the starch granule sizes of both pigeonpea and mung bean (Table 3 ). In general, pigeonpea starch granules were slightly bigger than the mung bean starch granules. Mung bean starch granule size varied from 9.5 to $47.5 \mathrm{u}$ with mean being $21.7 \mathrm{u}$ and pigeonpea between 9.5 and $55.1 \mathrm{u}$ with mean being $24.7 \mathrm{u}$. Of the various grain legumes, starch granule size was the smallest (range 12-32 u) for mung bean and highest (range 20-48 u) for faba bean as studied by Naivikul and D'Appolonia (1979).

Gelatinization temperatures are associated with the loss of birefringence characteristics of starch. The gelatinization temperature of pigeonpea starch $\left(76^{\circ} \mathrm{C}\right)$ was slightly higher than that of mung bean starch $\left(72^{\circ} \mathrm{C}\right)$, as shown in Table 4 . The ranges in gelatinization temperature of pigeonpea starches (65$71-76^{\circ} \mathrm{C}$ ) and mung bean starches $\left(61-65-72^{\circ} \mathrm{C}\right.$ ) are similar to those of chickpea $\left(63-65-76^{\circ} \mathrm{C}\right)$ and horse bean $\left(61-64-70^{\circ} \mathrm{C}\right)$ starches (Lineback and Ke, 1975), and of other legume starches such as kidney bean $\left(63-67-72^{\circ} \mathrm{C}\right.$ ) (Yang et al. 1980) and black bean (64-70-76 ${ }^{\circ} \mathrm{C}$ ) (Lai and Varriano-Marston, 1979). Gel strength of mung bean starch was higher than that of pigeonpea starch, whereas no large differences in gel consistency were observed.

The results indicated that the degree of syneresis of pigeonpea starch gel was higher than that of mung bean (Table 4). We also studied the degree of syncresis at different concentrations and observed that the degree of syneresis increased as the concentration of starch gel decreased. Lii and Chang (1981) also reported that degree of syneresis decreased remarkably from 6.7 at $7 \%$ starch concentration to 0.4 at $9 \%$ starch concentration. According to Yang et al. (1980), mung bean starch had a considerably lower degree of syneresis than other legume starches. The gel strength of pigeonpea starch was lower than 
Table 2-Per cent chemical composition of isolated starches of whole seed and dhal of pigeonpea (C 11) and mung bean (PS 16)

\begin{tabular}{|c|c|c|c|c|c|c|}
\hline Crop & $\begin{array}{c}\text { Starch } \\
\text { yield } \\
(\%) \\
\end{array}$ & $\begin{array}{c}\text { Starchb } \\
(\%)\end{array}$ & $\begin{array}{c}\text { Amylose } \\
(\%)\end{array}$ & $\begin{array}{c}\text { Protein } \\
(\%)\end{array}$ & $\begin{array}{l}\text { Ash } \\
(\%)\end{array}$ & $\begin{array}{c}\text { Crude } \\
\text { fiber } \\
\langle \%\rangle\end{array}$ \\
\hline \multicolumn{7}{|l|}{ Whole seed } \\
\hline $\begin{array}{l}\text { Pigeonpea } \\
\text { Mung bean } \\
\text { SE }\end{array}$ & $\begin{array}{l}49.3 \\
59.3 \\
\pm 3.79\end{array}$ & $\begin{array}{c}92.0 \\
90.9 \\
\pm 1.04\end{array}$ & $\begin{array}{l}46.9 \\
47.0 \\
\pm 1.23\end{array}$ & $\begin{array}{r}0.18 \\
0.14 \\
\pm 0.04\end{array}$ & $\begin{array}{r}0.04 \\
0.09 \\
\pm 0.02\end{array}$ & $\begin{array}{r}0.08 \\
0.11 \\
\pm 0.02\end{array}$ \\
\hline \multicolumn{7}{|l|}{ Dhal } \\
\hline $\begin{array}{l}\text { Pigeonpea } \\
\text { Mung bean } \\
\text { SE } \\
\end{array}$ & $\begin{array}{c}71.2 \\
78.9 \\
\pm 3.38\end{array}$ & $\begin{array}{c}93.6 \\
94.3 \\
\pm 1.20\end{array}$ & $\begin{array}{l}49.0 \\
50.3 \\
\pm 1.04\end{array}$ & $\begin{array}{r}0.17 \\
0.10 \\
+0.03\end{array}$ & $\begin{array}{r}0.03 \\
0.06 \\
+0.02\end{array}$ & $\begin{aligned} & 0.0 \\
& 0.05 \\
&+ 0.02\end{aligned}$ \\
\hline
\end{tabular}

a Means of two determinations, expressed on moisture-free basis.

betermined in isolated starch fraction.
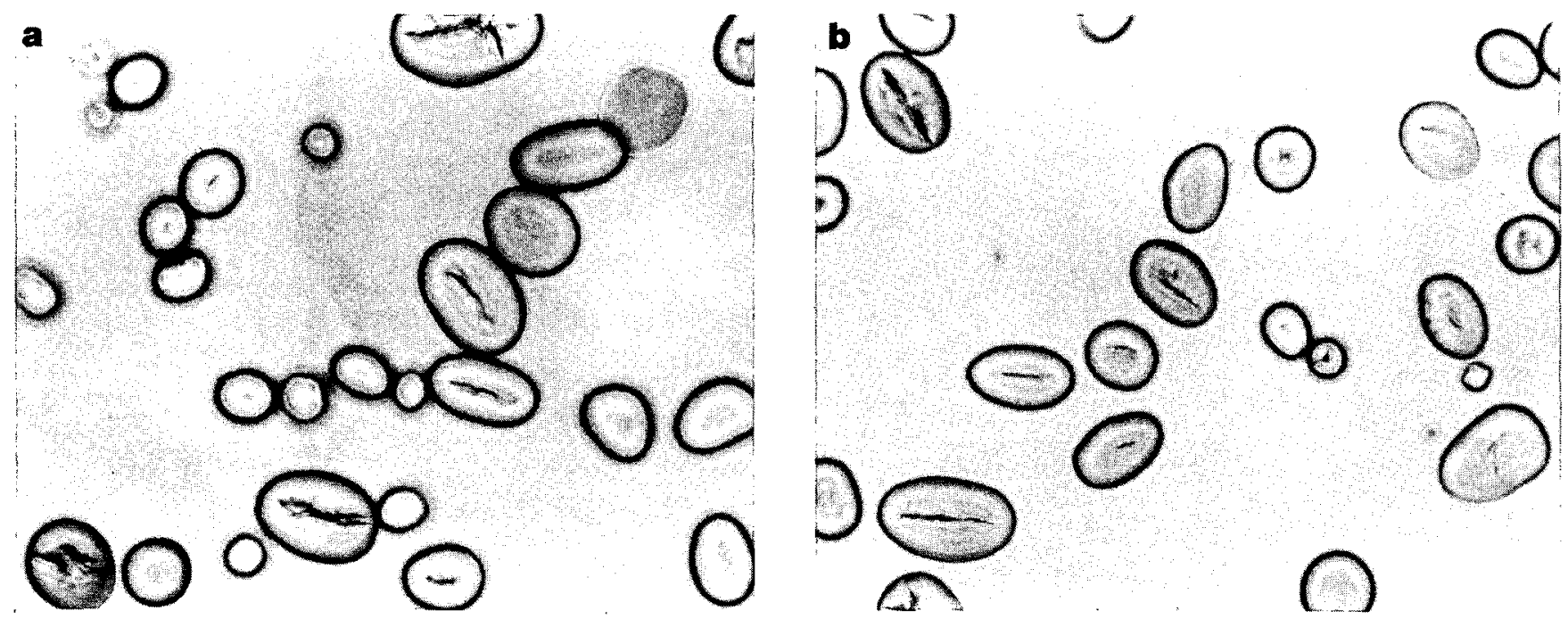

Fig. 1-Size and shape of starch granules $(600 \times)$ of pigeonpea (a) and mung bean (b).

Table 3-Shape and sizes of pigeonpea and mung bean starches

\begin{tabular}{lll}
\hline Crop & Shape & \multicolumn{1}{c}{ Size $(\mu)^{\mathrm{a}}$} \\
\hline Pigeonpea & Irregular & Range 9.5-55.1 \\
& (oval/round/bean-shaped) & Mean 24.7 \pm \\
& & $4.25^{\mathrm{b}}$ \\
Mung bean & Irregular & Range 9.5-47.5 \\
& (oval/round/bean-shaped) & Mean 21.7 \pm \\
& & $3.68^{\mathrm{b}}$ \\
\hline
\end{tabular}

a. Means of 100 measurements.

b Standard error

Table 4-Gelatinization temperature, ge/ strength, gel consistency and degree of syneresis of pigeonpea and mung bean starches ${ }^{a}$

\begin{tabular}{|c|c|c|c|c|}
\hline Crop & $\begin{array}{c}\text { Gel temp } \\
\left({ }^{\circ} \mathrm{C}\right)\end{array}$ & $\begin{array}{l}\text { Gel strength } \\
\text { (Force, kg) }\end{array}$ & $\begin{array}{l}\text { Gel consistencyc } \\
\text { (length, cm) }\end{array}$ & $\begin{array}{c}\text { Degree of } \\
\text { syneresis } \\
\left(\mathrm{ml} \mathrm{H} \mathrm{H}_{2} \mathrm{O}\right)\end{array}$ \\
\hline $\begin{array}{l}\text { Pigeonpea } \\
\text { Whole seed } \\
\text { Dhal } \\
\text { SE }\end{array}$ & 76 & $\begin{array}{l}1.4 \\
1.1 \\
\pm \\
0.03\end{array}$ & $\begin{aligned} & 3.0 \\
& 3.0 \\
\pm & 0.05\end{aligned}$ & $\begin{aligned} & 2.9 \\
& 3.2 \\
&+0.04\end{aligned}$ \\
\hline $\begin{array}{l}\text { Mung bean } \\
\text { Whole seed } \\
\text { Dhal } \\
\text { SE }\end{array}$ & 72 & $\begin{aligned} & 2.5 \\
& 1.7 \\
\pm & 0.04\end{aligned}$ & $\begin{aligned} & 3.3 \\
& 2.8 \\
\pm & 0.05\end{aligned}$ & $\begin{array}{c}1.1 \\
1.1 \\
\pm 0.02\end{array}$ \\
\hline
\end{tabular}

- All results are means of two determinations.

b Temperature at which $90 \%$ starch granules were stained.

Determined after heating $6 \%$ starch solution at $95^{\circ} \mathrm{C}$ for $5 \mathrm{~min}$ and after standing at room temperature for $30 \mathrm{~min}$.

d Determined as the volume of water $(\mathrm{mL})$ separated from $35 \mathrm{~mL}$ of starch gel after storage of $6 \%$ starch solution at $4^{\circ} \mathrm{C}$ for $12 \mathrm{hr}$.

that of mung bean (Table 4). The lower gel strength has been attributed to its low iodine affinity and lower amylose content (Lii and Chang, 1981). But in the present study, no noticeable differences in amylose content of mung bean and pigeonpea starches were observed (Table 2), implying that differences in the gel strength of these two legumes may not be attributable to their amylose content.

The starch granules are held together by hydrogen-bonding forces in the form of crystalline bundles, called micelles (Leach et al., 1959). When an aqueous suspension of starch granules is heated, these structures are hydrated and eventually swelling take place. The swelling power of pigeonpea and mung bean starches at different temperatures is presented in Fig. 2. The patterns of swelling power of mung bean and pigeonpea starches showed marked differences, particularly at lower temperatures (Fig. 2). Mung bean starch swelled more rapidly at relatively lower temperatures than pigeonpea, whereas the swelling powers of pigeonpea and mung bean starches were comparable at higher temperatures. From the data, it appeared that both mung bean and pigeonpea starches were exemplified by a two-stage swelling process, i.e., the initial swelling followed by a period of rapid rate of swelling (Fig. 2). This behavior was attributable to two sets of bonding forces with relaxation at different temperature levels, a weak association relaxing at $65-75^{\circ} \mathrm{C}$, and a second and stronger association relaxing at $85-95^{\circ} \mathrm{C}$ as speculated by Leach et al. (1959). Solubility of starches of these two legumes did not show large differences (Fig. 2).

The Bradender viscosity patterns of starches are primarily determined by (1) the extent of swelling of the starch granules; and (2) the resistance of the swollen granules to dissolution by heat or fragmentation by shear. Having observed differences in the swelling power of pigeonpea and mung bean starches, their viscosity patterns at different temperatures were examined. The Brabender viscosity patterns of $6 \%$ starch pastes of pigeonpea and mung bean gave no pasting peak during heating at $95^{\circ} \mathrm{C}$. Both showed a stable graph, indicating that there was no breakdown of the hot paste. Such a pattern is similar to most of the legume starch pastes and could be classified into 


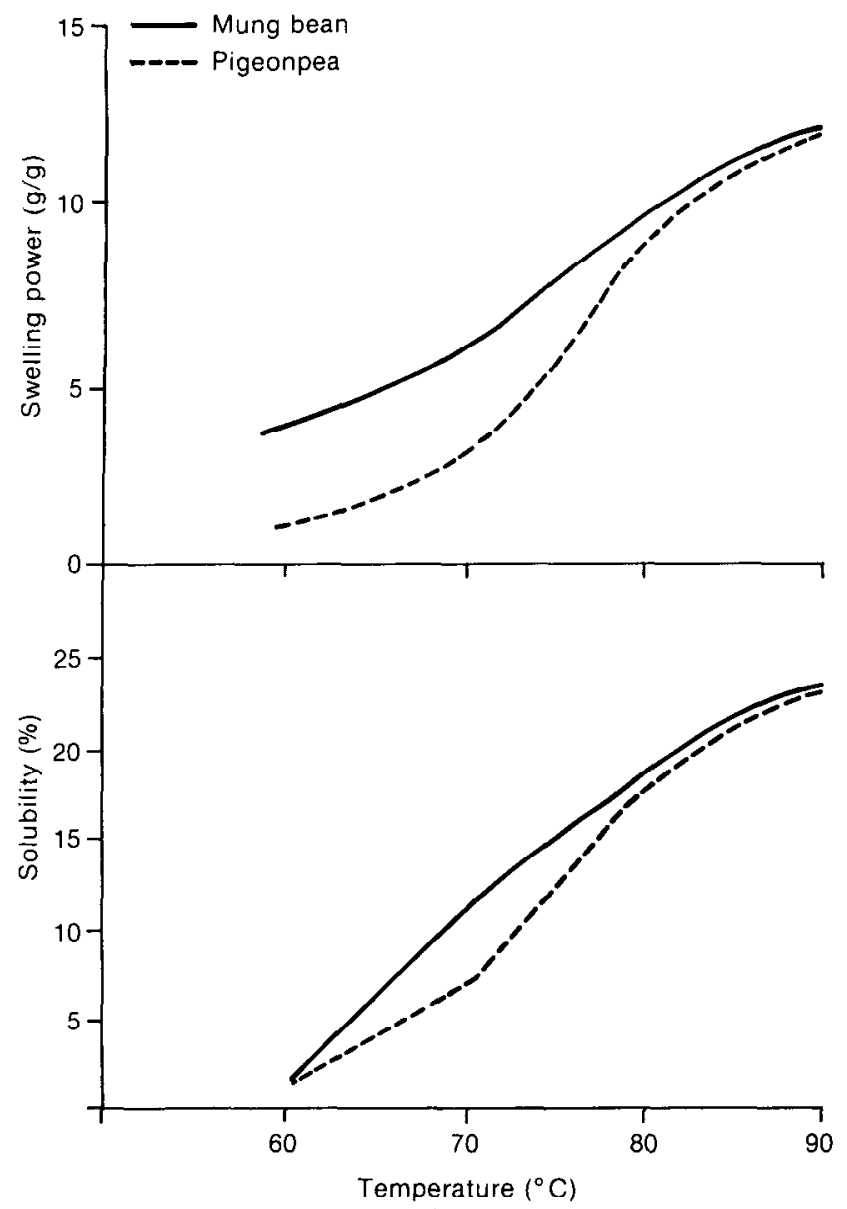

Fig. 2-Swelling power and solubility patterns of mung bean and pigeonpea starches.

Table 5-Viscoamylographic properties of dhat starches $^{\mathrm{a}}$ of pigeonpea and mung bean

\begin{tabular}{|c|c|c|c|c|c|}
\hline \multirow[b]{3}{*}{ Crop } & \multicolumn{4}{|c|}{ Viscosity (Brabender units) } & \multirow[b]{3}{*}{ Set back ${ }^{\circ}$} \\
\hline & \multicolumn{2}{|c|}{$95^{\circ} \mathrm{C}$} & \multirow[b]{2}{*}{$50^{\circ} \mathrm{C}$} & \multirow[b]{2}{*}{$35^{\circ} \mathrm{C}$} & \\
\hline & Initial & Final $^{\mathrm{b}}$ & & & \\
\hline $\begin{array}{l}\text { Pigeonpea } \\
\text { Mung bean }\end{array}$ & $\begin{array}{l}277 \\
300\end{array}$ & $\begin{array}{l}302 \\
315\end{array}$ & $\begin{array}{l}480 \\
665\end{array}$ & $\begin{array}{l}593 \\
972\end{array}$ & $\begin{array}{l}178 \\
350\end{array}$ \\
\hline SE & \pm 6.5 & $\pm \quad 5.8$ & \pm 12.4 & \pm 15.8 & \pm 7.9 \\
\hline
\end{tabular}

a Values obtained using $6 \%$ starch and averaged over two determinations.

b After holding for $60 \mathrm{~min}$.

c Difference of reading at $50^{\circ} \mathrm{C}$ and after holding for $60 \mathrm{~min}$ at $95^{\circ} \mathrm{C}$.

type C of Schoch's classification (Schoch and Maywald, 1968). No values were reported for peak viscosity because no distinct peak was obtained with the legume starches as was normally found with wheat starch (Naivikul and D'Appolonia, 1979). Marked differences in viscosity patterns of pigeonpea and mung bean starches were observed, however, at different temperatures (Tables 5). The viscosity patterns of these legumes appeared to be related to their swelling power. Interestingly, the viscosity of pigeonpea starch at lower temperatures $\left(35^{\circ} \mathrm{C}\right.$ and $50^{\circ} \mathrm{C}$ ) was remarkably lower than that of the mung bean starch. As mentioned above, the swelling power of pigeonpea starch at lower temperatures was also noticeably lower than that of mung bean starch. The extent of increase in viscosity on cooling to $50^{\circ} \mathrm{C}$ reflected a retrograde tendency in the starch molecules. Pigeonpea starch showed a much lower set-back value than mung bean starch (Table 5).

\section{Noodle quality}

The noodle quality of both whole seed and dhal of pigeonpea and mung bean was examined by sensory evaluation. Sensory properties, such as color, texture, clarity, and general acceptability, were evaluated, using soft and hard noodles, and the results are presented in Table 6 . Soft noodles of pigeonpea and mung bean starch are shown in Fig. 3 .

Starch extracted from whole seed and dhal samples of these legumes showed noticeable differences in their noodle qualities (Table 6). The whole-seed starch isolated from pigeonpea produced noodles with poor to fair quality, with an average score of 1.9 on general acceptability, whereas the noodles of wholeseed starches of mung bean were rated as fair to good with an average score of 2.8 (Table 6 ). The scores on noodle clarity and color from whole seed starch of pigeonpea were lower than those of the mung bean. Dhal starch of pigeonpea produced noodles with better quality than that of mung bean, as revealed by various sensory properties (Table 6) and noodle color. This was due to the brighter color of pigeonpea dhal starch as no pigments were extracted along with the starch. On the other hand, some starch bound pigments might have been extracted in the case of mung bean dhal starch. No marked differences were observed in the quality of hard noodle of mung bean and pigeonpea dhal starches (Table 6). These results indicate that in the case of whole seed starch, noodle quality was better for mung bean than for pigeonpea whereas the reverse was true, except for texture, for dhal starch (Table 6). Quality of hard noodle made from dhal starch of pigeonpea or mung bean was comparable.

\section{CONCLUSIONS}

THE STARCH YIELDS from both whole seed and dhal samples of mung bean were higher than those of pigeonpea indicating that starch was more extractable from mung bean than from pigeonpea. Amylose values of mung bean and pigeonpea starches were comparable. Although there were differences in swelling power of mung bean and pigeonpea starches at lower temperatures, both legumes showed restricted swelling and a C-type Brabender viscosity curve; they thus possessed desirable starch qualities for noodle manufacture. Sensory tests also indicated that from whole seed starch, the noodle quality was better in mung bean than in pigeonpea. But starch from pigeonpea dhal was as good for noodle preparation as that from mung bean dhal perhaps even better, due to the bright color of pigeonpea dhal starch. Although the present results were based on analysis of a limited number of samples, it was apparent that pigeonpea could be used as a potential starch source for making transparent noodles. Additional studies, using cultivars with variable seed coat color of these legumes would be useful to know the influence of seed coat pigments on starch color and noodle quality. The effect of fiber components on starch yields of mung bean and pigeonper also needs to be investigated. As pigeonpea dhal starch was brighter than mung bean dhal starch, the extraction of pigments along with the starch in the case of mung bean needs to be investigated in

Table 6-Sensory scores of soft and (hard) noodles of pigeonpea and mung bean starch ${ }^{\circ}$

\begin{tabular}{lccccc}
\hline Crop & Color & Texture & Clarity & $\begin{array}{c}\text { Uniform } \\
\text { appearance }\end{array}$ & $\begin{array}{c}\text { General } \\
\text { acceptability }\end{array}$ \\
\hline $\begin{array}{l}\text { Pigeonpea } \\
\text { Whole seed }\end{array}$ & 1.6 & 2.0 & 1.7 & 2.3 & 1.9 \\
Dhal & 3.6 & 2.6 & 3.5 & 3.4 & 3.4 \\
& $(3.7)$ & $(3.1)$ & $(3.0)$ & $(3.2)$ & $(3.1)$ \\
$\begin{array}{l}\text { Mung bean } \\
\text { Whole seed }\end{array}$ & 2.5 & 3.2 & 2.5 & 2.8 & 2.8 \\
Dhalb & 2.8 & 2.9 & 2.6 & 2.3 & 2.6 \\
& $(3.3)$ & $(3.2)$ & $(3.2)$ & $(2.8)$ & $(3.0)$ \\
SEb & \pm 0.34 & \pm 0.27 & \pm 0.30 & \pm 0.26 & \pm 0.30 \\
& $( \pm 0.23)$ & $( \pm 0.08)$ & $( \pm 0.17)$ & $( \pm 0.34)$ & $( \pm 0.12)$ \\
\hline
\end{tabular}

a Mean values of ten panel members. Rating scale: $4=$ excellent, $3=$ good, $2=$ fair, and $1=$ poor.

b Values within parentheses are for hard noodles. 


\section{Noodles}

\section{Mungbean}

\section{Pigeonpea}

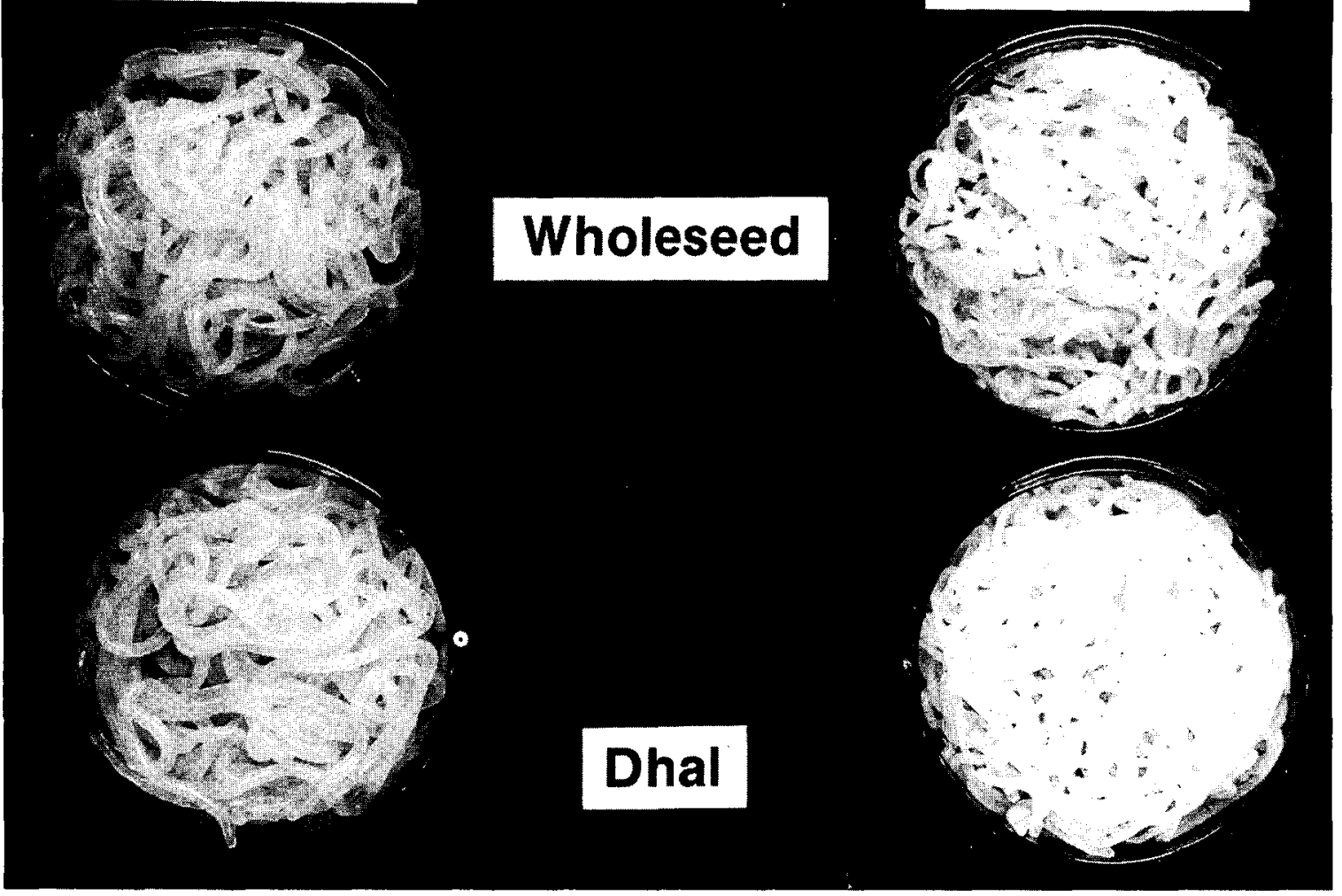

Fig. 3-Starch noodle of whole seed and dhal samples of pigeonpea and mung bean.

detail in view of the large scale utilization of mung bean starch for making transparent noodle in several Asian countries.

\section{REFERENCES}

AOAC, 1975. "Official Methods of Analysis," 12th ed. Association of Official Analytical Chemists, Washington, DC.

Biliaderis, C.G., Grant, D.R., and Vose, J.R. 1979. Molecular weight distribution of legume starches of gel chromatography. Cereal Chem. 56: 475.

Bressani, R. 1973. Legumes in human diets and how they might be improved. In "Nutritionl Improvement of Food Legumes by Breeding," $\mathrm{M}$. Milner (Ed.) p. 15. United Nations, New York.

Chen, C.Y. 1978. The noodle qualities and physicochemical properties of various starches isolated by wet process. M.S. thesis, National Taiwan various starches isolated by

Univ., Taipei, Taiwan, R.O.C.
ICRISAT, 1981. Annual Report 1980, International Crops Research InstiICRISAT, 1981. Annual Report 1980, International Crops Research Insti-
tute for the Semi-Arid Tropics, Patancheru, A.P. 502 324, India, p. 138. Lai, C.C. and Varriano-Marston, E. 1979. Studies on the characteristics of black bean starch. J. Food Sci. 44:528

Leach, H.W., Mc Cowen, L.D. and Schoch, T.J. 1959. Structure of the starch granule. I. Swelling and solubility patterns of various starches. Cereal Chem. 36: 534.

Lii, C.Y. and Chang, S.M. 1981. Characterization of Red Bean (Phaseolus radiatus var. Aurea) starch and its noodle quality. J. Food. Sci. 46: 79

Lii, C.Y., Chen, C.Y., and Wang, H.H. 1979. Studies on the processings Li, C.Y., Chen, C.Y., and Wang, H.H. 1979. Studies on the processings aC qualities of starch noodles from various starchs. Prese

ACS-CSJ Joint Meeting, Honolulu, Hawaii, April 1-6, 1979.
Lineback, D.R. and Ke, C.H. 1975. Starches and low molecular weight carbohydrates from chickpea and horse beans flours. Cereal Chem 52 : 334

Naivikul, O. and D'Appolonia, B.L. 1979. Carbohydrates of legume flours compared with wheat flour. II. Starch. Cereal Chem. 56: 24.

Radley, J.A. 1976. "Examination and Analysis of Starch and Starch Products," p. 220. Applied Science, London

Schoch, T.J. and Maywald, E.C. 1968. Preparation and properties of various legume starches. Cereal Chem. 45:564.

Singh, U. and Jambunathan, R. 1981. Methods for the estimation of protein in pigeonpea (Cajanus cajan $\mathrm{L}$.) and the relationship between whole grain and dhal protein contents. J Sci. Food Agric. 32:705.

Singh, U., Jambunathan, R., and Narayanan, A. 1980 . Biochemical changes in developing seeds of pigeonpea (Cajanus cajan L.). Phytochemistry 19 1291

Singh, U. Seetha, R., Rao, P.V., and Jambunathan, R. 1989. Nutrient losses due to scarification of pigeonpea (Cajanus cajan L.) cotyledons. J. Food Sci. 54: 974.

Snedecor, G.W. and Cochran, W.C. 1967. One-way classification: Analysis of variance. In "Statistical Methods," 6th ed. p. 260. Oxford \& IBH Publishing Co., New Delhi, India.

Tjahjadi, C. and Breene, W.M. 1984. Isolation and characterization of adzuki bean (Vigna angularis) starch. J. Food. Sci. 49:558.

zuki bean (Vigna angularis) starch. J. Food. Sci. 49: 558. Williams, V.R., Wu, W.T., Tsai, H.Y., and Bates, H.C. 1958. Varietal dif-

Yang, C.C., Change, S.M., and Lii, C.Y. 1980. Studies on the starches in

Taiwain. 4. Kidney bean. Bull. Inst. Chem. Acad. Sinica. 27: 37

Ms received 9/22/88; revised 1/25/89; accepted 2/11/89.

Submitted as Journal Article \#813 by ICRISA'T 